\title{
REMOTE SENSING OF SUSPENDED SEDIMENT OVER GULF OF MARTABAN
}

\author{
ABD RAHMAN MATAMIN ${ }^{1,2}$, FADHLI AHMAD ${ }^{2}$, MUSTAFA MAMAT ${ }^{3}$, KHIRUDDIN $^{2}$ \\ ABDULLAH $^{4}$, SHAHARIAH HARUN ${ }^{1}$ \\ ${ }^{1}$ Faculty of Applied Science, Universiti Teknologi MARA Terengganu, Kampus Kuala Terengganu, 21080 Kuala \\ Terengganu, Malaysia; e-mail: arman38@yahoo.com \\ ${ }^{2}$ School of Ocean Engineering, Universiti Malaysia Terengganu, 21030 Kuala Terengganu, Terengganu, Malaysia \\ ${ }^{3}$ Fakulti Informatik dan Komputeran, Universiti Sultan Zainal Abidin, Kampus Tembila, 22200 Besut, Terengganu, \\ Malaysia \\ ${ }^{4}$ School of Physics, Universiti Sains Malaysia, 11800 Minden, Malaysia
}

\begin{abstract}
MatAmin A.R., Ahmad F., Mamat M., Abdullah K., Harun S.: Remote sensing of suspended sediment over Gulf of Martaban. Ekológia (Bratislava), Vol. 34, No. 1, p. 54-64, 2015.

Gulf of Martaban is located at the north of Andaman, and is one of the world most turbid areas. The presence of suspended sediment concentration (SSC) in the water body could reduce the underwater transmittance. This study has been conducted to investigate the variation of SSC over the Gulf of Martaban. Remote sensing reflectance (Rrs) of $667 \mathrm{~nm}$ is used as a proxy to represent the sediment SSC variation over the study area. The data for the period of July 2002 to March 2014 acquired from MODIS Aqua $4 \mathrm{~km}$ resolution are used in this study. As a result, there is no obvious yearly variation in the SSC cover area. The SSC variation over this study area is found to be seasonal. High homogenous SSC covers area observably during the northeast (NE) monsoon season that occurs from December to January. The sediment cover area could reach the latitude of $15^{\circ} \mathrm{N}$ that located at the south of the gulf. During southwest (SW) monsoon season that occurs from May to September, low and sparse SSC cover area is observed. As a consequence, the area covered by the SSC is higher during the NE monsoon season as compared to the SW monsoon season. Hence, the SSC cover area during the NE monsoon season is greater than the yearly averaged SSC cover area. Meanwhile the SSC cover area during the rainy SW monsoon season is less than the yearly and NE monsoon season.
\end{abstract}

Key words: suspended sediment concentration, MODIS, monsoon, turbidity.

\section{Introduction}

The presence of sediment over turbid coastal water could be indicated by the brownish colour in the remote sensing image. For the purpose of this study, sediment is defined as comprising of both organic and inorganic material. The distribution of sediment are highly varies in coastal and estuaries environments and also over a broad spectrum of time and space scales. This variability renders most traditional field sampling methods as inadequate (Miller, McKee, 2004; Pavelsky, Smith, 2009). The presences of remote sensing technology offer an 
alternative way for tracking spatial and temporal variation of suspended sediment concentration (SSC). However, most of the remote sensing instruments characteristics such as their associated costs, the ground resolution and the revisited day could limit the application to monitor sediment dynamic over the coastal water and estuaries (Miller, McKee, 2004). To obtain the huge spatial and long temporal data for the zero cost is one of the challenging issues. The launch of the Goddard interactive online visualisation and analysis infrastructure (Giovanni) could offer a user friendly web-based environment to explore interactively various remote sensing oceanic and atmospheric data (Leptoukh et al., 2007). One of the characteristic of this web-based environment is it can plot desired graph for the long time period for numerous remote sensing data.

The fact that the suspended sediments increase the radiant emergent from surface waters in the visible and near infrared region of the electromagnet spectrum has been made since late 1970s (Ritchie et al., 1976). A number of researchers conclude that the sediment concentration have found to be linear and curvilinear relationship between suspended sediments and radiance or reflectance (Ritchie et al., 1976; Curran, Novo, 1988; Doxaran et al., 2003; Wang et al., 2008; Miller, McKee, 2004; Chu et al., 2009; Long, Pavelsky, 2013). The usage of the red portion of the electromagnetic spectrum over turbid water is well documented. This is because, the scattering from suspended material is frequently dominant in this spectrum region when compared to the pure water, phytoplankton and coloured dissolved organic matter (CDOM) (Kirk, 1994; Mobley, 1994). Miller and Mckee (2004) have found that the Rrs of red channels of MODIS sensor could be successfully utilised to map SSC over turbid productive water. Additional evidence from the other investigators shows that the red portion of the electromagnetic spectrum could be utilised to examine water quality parameter related to SSC (Hu et al., 2004; Chen et al., 2007; Rodriguez-Guzman et al., 2009; Petus et al., 2010; Moreno-Madrinan et al., 2010).

The main objective of this study is to investigate SSC patterns, area coverage and the possible influences factor over the Gulf of Martaban by utilising Giovanni web-based environment. In this study, remote sensing reflectance (Rrs) of $667 \mathrm{~nm}$ acquired from MODIS Aqua $4 \mathrm{~km}$ is used as a proxy to represent the SSC dominated area. Any increment in the Rrs $(667 \mathrm{~nm})$ value is indicated that the heightened in the SSC value.

\section{Study area}

Figure 1 shows the map of Gulf of Martaban and nearby area. Geographically Gulf of Martaban is located at the northern Andaman Sea. In general, the Andaman Sea is a body of water to the southeast of the Bay of Bengal, south of Myanmar, west of Thailand and east of the Andaman Islands that is part of the Indian Ocean. It is roughly 1,200 $\mathrm{km}$ (north-south) and $650 \mathrm{~km}$ wide (east-west), with an area of 797,700 $\mathrm{km}^{2}$. Its average depth is $870 \mathrm{~m}$, with the maximum depth of $3,777 \mathrm{~m}$. The study area roughly covers the latitude range of $12.5^{\circ} \mathrm{N}-18^{\circ} \mathrm{N}$ and the longitude of $92.5^{\circ} \mathrm{E}-99.5^{\circ} \mathrm{E}$.

The northern Indian Ocean, including the Andaman Sea and Gulf of Martaban, is characterised by the seasonally reversing Asian monsoon (Wyrtki, 1973). The northeast (NE) monsoon season is active between December to February. The southwest (SW) monsoon, also known as rainy season, is active between mid May and end of September. Practically, all of the rainfall receives during this season. The coastal regions and the western and south eastern ranges receive more than $5,000 \mathrm{~mm}$ of precipitation annually, while the delta regions receive about 2,500 $\mathrm{mm}$ (Hadden, 2008). Annually more than 350 million tons of sediment deposited into this area by the Ayerrarwady, Salween and Sittang rivers system (Ramaswamy et al., 2004; Robinson et al., 2007). 


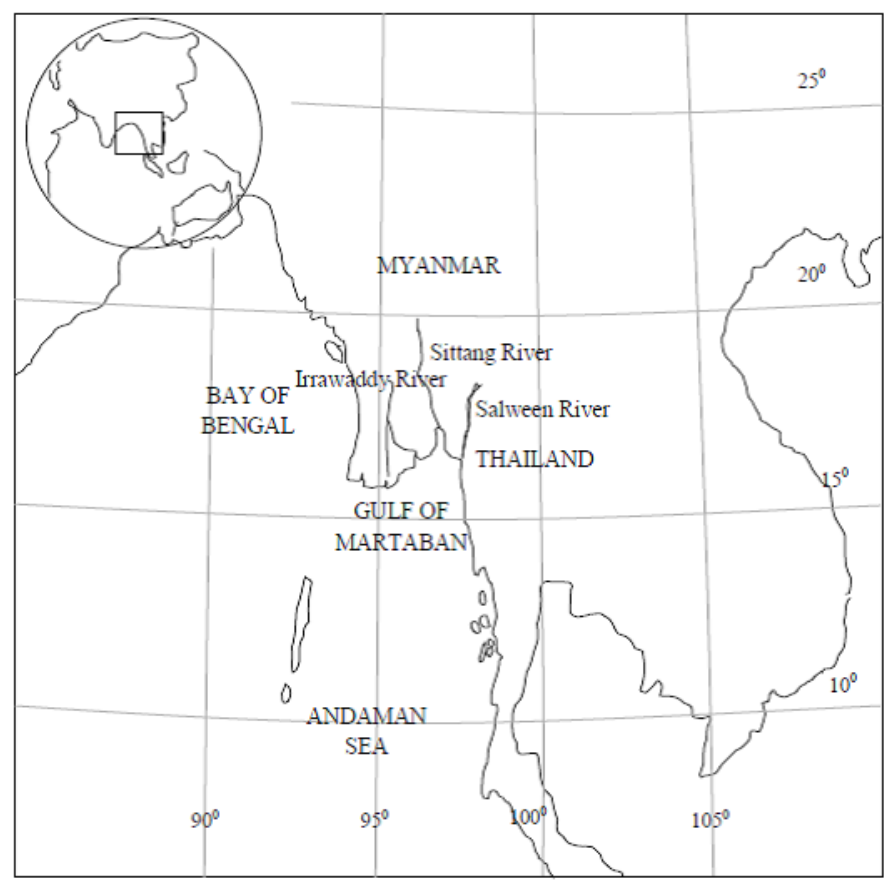

Fig. 1. Study area.

\section{Methodology}

Moderate Resolution Imaging Spectroradiometer (MODIS) data with high temporal resolution is used in this study. High temporal resolutions provide the continuation in the data collection. MODIS was launched aboard Terra satellite in late 1999 and aboard Aqua satellite in early 2002. Both satellites are polar-orbiting, with Terra on a descending orbit (southward) over the equator about 10:30 local sun time, and Aqua on an ascending orbit (northward) over the equator about 13:30 local sun time. MODIS will view the entire surface of the Earth every 1-2 days. MODIS performs measurements in the visible to thermal infrared spectral region from 0.41 to $14.235 \mu \mathrm{m}$ (Salomonson et al., 1989). The MODIS instruments measure spectral radiance in 36 channels, in resolutions between $250 \mathrm{~m}$ and $1 \mathrm{~km}$ (at nadir). MODIS have distribute numbers of high quality images through theirs data distribution website.

Remote sensing reflectance is defined as the ratio of radiance leaving the water (upwelling) to irradiance incident on the water (downwelling). It is so-named because it indicates the effective reflectance of a body of water when viewed by a remote sensor such as an airborne or satellite radiometer (http://www.hobilabs.com/). Although the daily and 8 day's data also provided, but due to the geography of the study area that mainly influence by the cloud, the monthly product is used in this study. The data product is averaged so, the effect of the clouds cover could be minimised. There are five remote sensing reflectance product that distributed by Giovanni ocean portal instances. However, in this study Rrs of $667 \mathrm{~nm}$ is used as a TSS index over the coastal line and rivers mouth. The Rrs of 667 $\mathrm{nm}$ used in this study is MODIS Aqua Level 3 product with $4 \mathrm{~km}$ resolution. This product is processed by the NASA Ocean Biology Processing Group (OBPG). The Rrs of $667 \mathrm{~nm}$ of MODIS Aqua is used as a key indicator of the sediment patent along the coastal line and river mouth. Input data are taken from the Giovanni (Goddard Earth Sciences Data and Information Services Center, Interactive Online Visualization and Analysis Infrastructure) (Acker, Leptoukh, 2007). The Giovanni online data system was developed and maintained by the NASA GES DISC. Image and remote sensing reflectance for the study area is then downloaded. Analyses and visualisations used in this study produced with the Giovanni online data system, developed and maintained by the NASA GES DISC. 


\section{Result}

\section{Yearly SSC Anomaly}

Recently, the SSC algorithms proposed by numbers of researcher are regional basis. Due to the absence of the ground truth data, the discussion in this paper only will be made qualitatively. Figure 2 shows the Rrs $(667 \mathrm{~nm})$ that will be used as a proxy to the SSC anomaly over the Gulf of Martaban for the period of July 2002 to March 2014. Clear water area is represented by the dark purple colour that mostly located over the Andaman Sea that is located in the south and the Bay of Bengal that is located at the western part of the Gulf of Martaban. As shown by the figure, the highest SSC was observed near the coastal line which is represented by the green to yellow colour. The high SSC is observed along the coastal line of the north and the east portion of the gulf. As we move far from the coastal line to the south, the SSC are becoming slightly lower and diminished in the Andaman Sea. The annual SSC is covering an area roughly latitude of $15^{\circ} \mathrm{N}$ to $17^{\circ} \mathrm{N}$ and the longitude $94^{\circ} \mathrm{E}$ to $98^{\circ} \mathrm{E}$. The decrement in the SSC is represented by the light blue to the dark blue colour. However, due to the presence of high SSC, no data could be retrieved as shown by the white colour region that located over the river mouth and along the coastal line. The lost in data are due to the saturation of the $667 \mathrm{~nm}$ wavelength. The light purple colour areas that are visible in Figure 2 indicate where the SSC was significantly less than the average SSC for the study period.

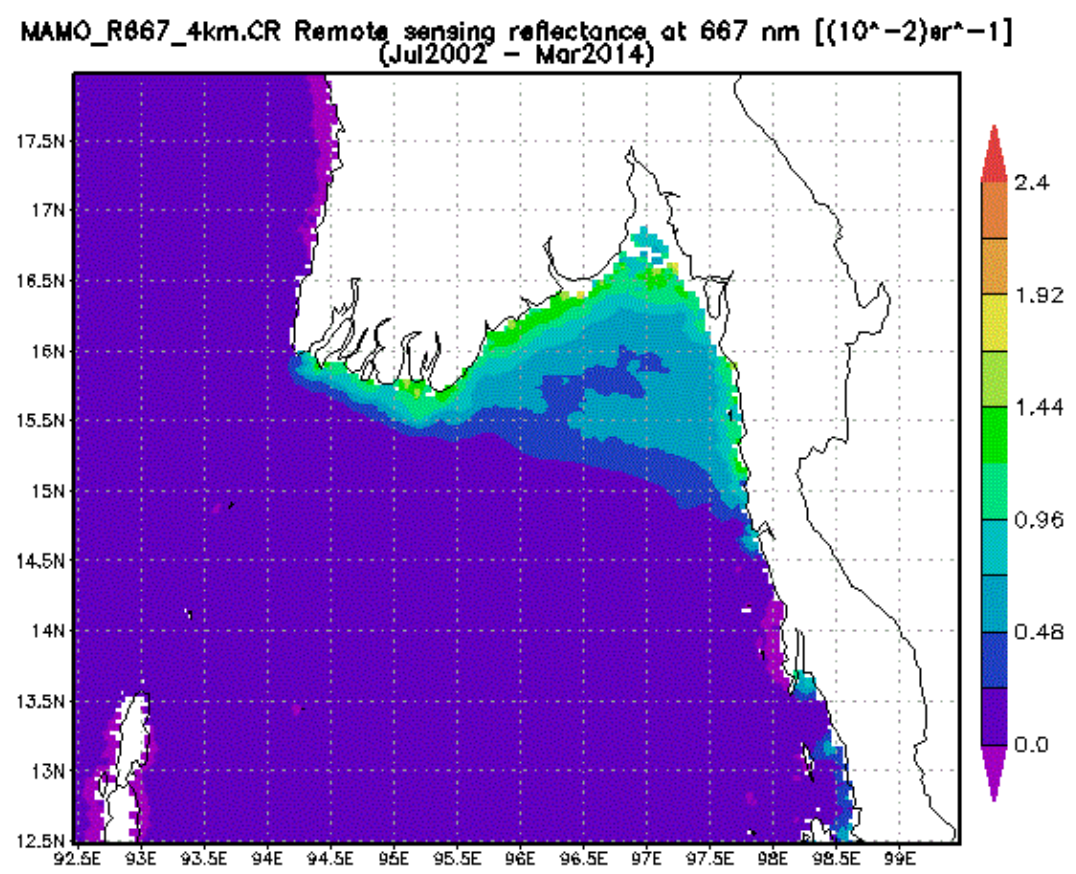

Fig. 2. Rrs $(667 \mathrm{~nm})$ for the period of July 2002 to March 2014. 
The Rrs $(667 \mathrm{~nm})$ area-averaged time series is shown by Figure 3. The time series covered the period from July 2002 to March 2014. For the monthly variation, generally the high SSC is observed from December to February. Meanwhile, the lowest SSC is observed from June to July. An increment in SSC can be observed starting from October to January for every year. The Rrs data for the August 2004 and July 2006 could not be used due to the study area is highly covered by clouds. The SSC trend starts to decrease from January to May for every year which the lowest value is from May to July. Seasonal variation shows that the SSC value is higher during NE monsoon season as compared to the SW monsoon season.

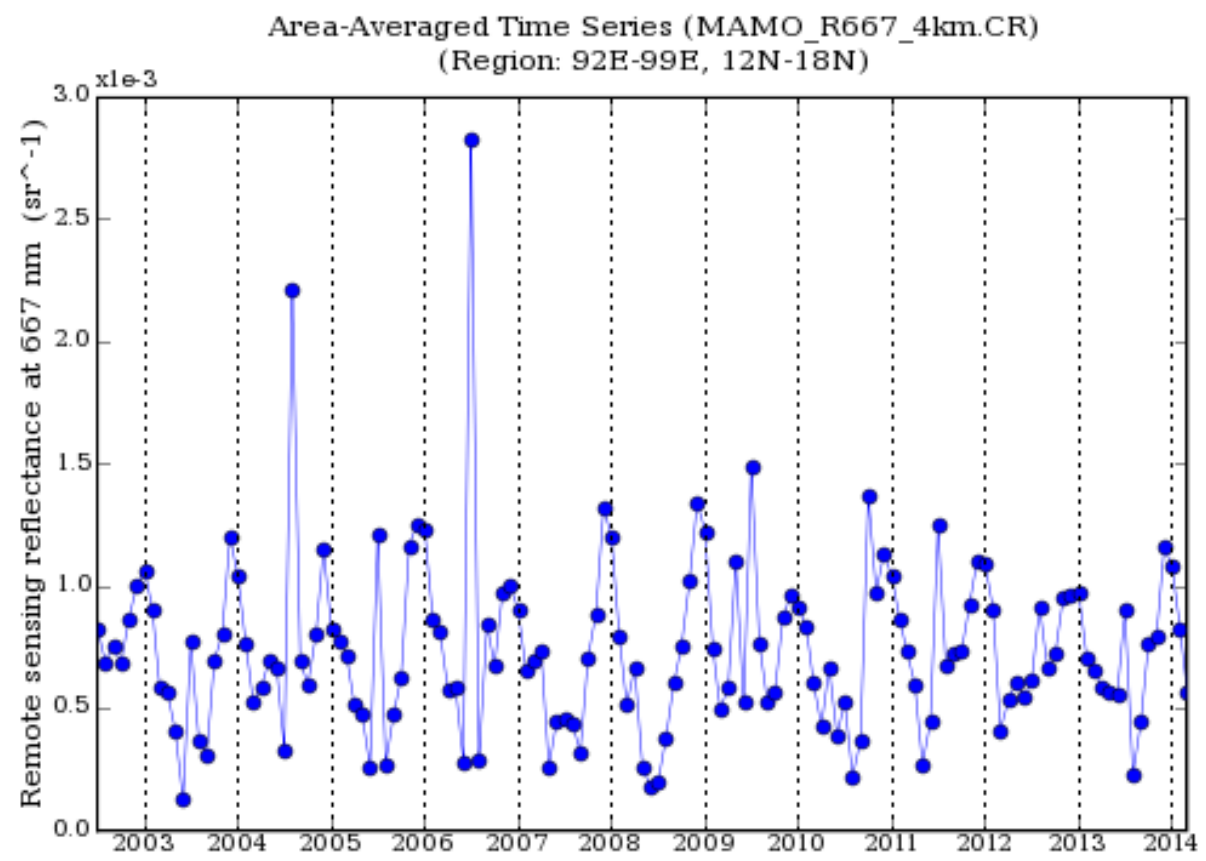

Fig. 3. Monthly Rrs (667 nm) area-averaged time series for the period of July 2002 to March 2014 .

\section{Seasonal SSC Anomaly}

Figure 4 shows the sample image of the seasonal SSC anomaly over the study area. Figure 4(a) represents the SSC anomaly for the SW monsoon season of May 2004-September 2004. White colour that appears over the water area represented by the cloud covered area. During SW monsoon season, the presence of numbers of cloud covers in the study area could lead to the loss in the valuable data. This phenomenon could be the factor for the unsuitable to use single day image to study the SSC over this area during SW monsoon season. The SSC 


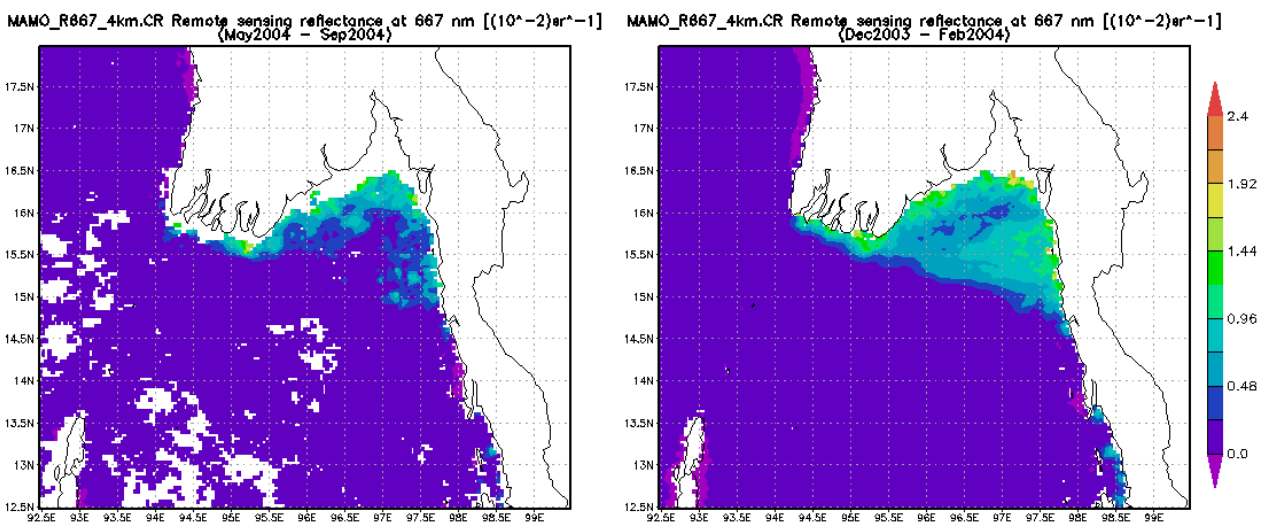

Fig. 4. Rrs (667 nm) anomaly over the study area for; (a) SW monsoon season May 2004-September 2004; (b) NE monsoon season December 2003-February 2004.

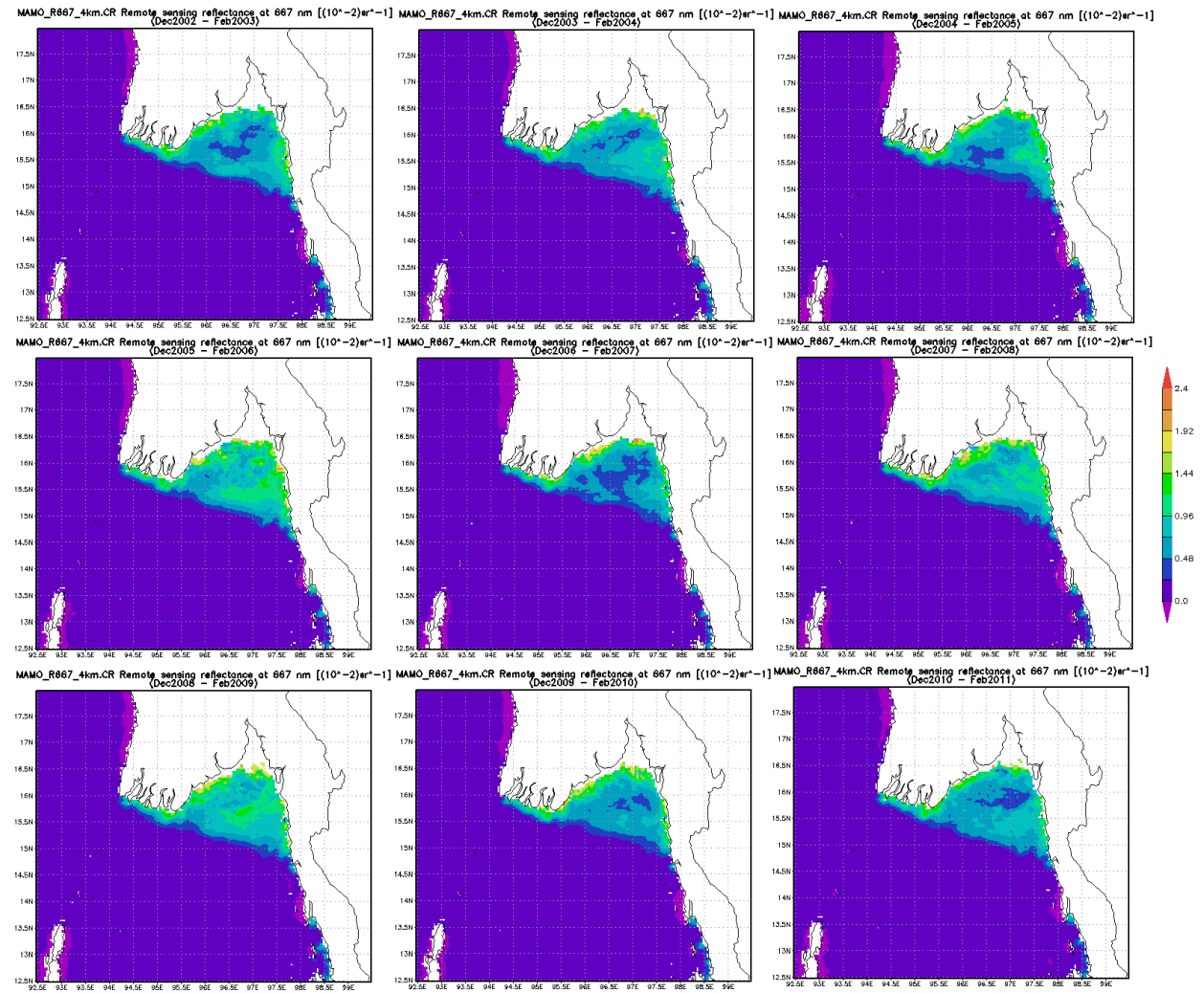

Fig. 5. Remote sensing reflectance over the study period during NE monsoon season. 


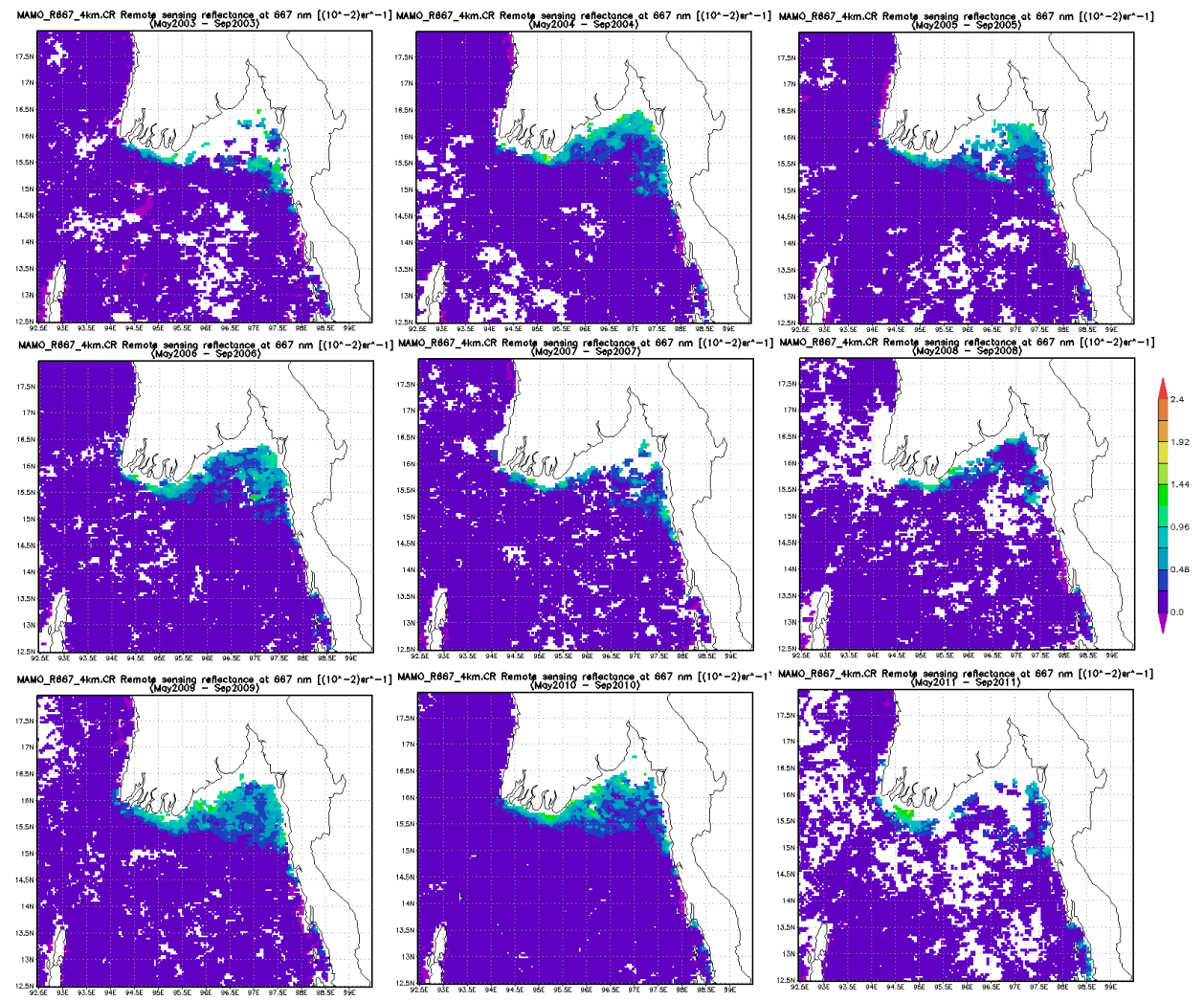

Fig. 6. Remote sensing reflectance over the study period during SW monsoon season.

anomaly for the NE monsoon season is shown by the Figure 4(b). During NE monsoon season, high SSC covered area is observed as compared to the SW monsoon season. The sediment cover area could stretch to the south and could reach the $15^{\circ} \mathrm{N}$. For the both seasons, white colour that can be seen at the north of the gulf and over the river mouth indicates the high SSC area that could saturate the $667 \mathrm{~nm}$ channel. As a comparison, the SSC cover area is greater for the NE monsoon season compared to SW monsoon season.

Figure 5 shows the SSC anomaly for the nine NE monsoons season period from 2002 to 2010. The highest SSC that is represented by the orange colour mostly located at the north and the east portion of the image. Further to the north or to the coastal line, no SSC value is observed. This is because of the saturation of the channel due to the very high sediment reflectance. The non-value pixels are represented by the white colour that can be seen along the coastal line and river mouths. Meanwhile the moderate SSC value is located over the edge of the turbidity zone that represented by the dark blue colour. Generally, the sediment cover areas for the nine monsoon season shown are appearing quite the same. No significant different in the SSC cover area for all seasons. 
The SSC variation for the SW monsoon season is shown by the Figure 6. As compared to the Figure 5, the SSC covered area for the SW monsoon season is much less than NE monsoon season. During SW monsoon season, the study area is mostly contaminated by the clouds. The presence of clouds is represented by the white sparse colour that scattered over the water region. Sparse SSC could be seen over the edge of the turbidity zone. However, the main difference between these two seasons is the high SSC concentration cover area. During the NE monsoon season, a very high SSC covered area can be seen at the north of the gulf and along the coastal line. This area where is the $667 \mathrm{~nm}$ channel is saturated represented by the white colour.

\section{Discussion}

In this study, 11 years averaged SSC is used as a based. The above result shows that the SSC over the Gulf of Martaban are highly seasonal dependence. During the NE monsoon season, the SSC covered area is higher as compared to the 11 years anomaly. Meanwhile, during the NE monsoon season, the SSC covered area is much lower than the 11 years anomaly. Furthermore, higher SSC covered area is observed during the NE monsoon season as compared to the SW monsoon season whereas the sediment covered areas more homogenous in space. The increment or decrement in the SSC covered area could be influence by the several factors.

\section{Monsoon Wind}

Figure 7 shows the NE and SW monsoon wind condition over the study area. During the NE monsoon season, the winds are originated from the north and northeast and directed towards the southwest (Rizal et al., 2012). Although the wind speed over the Gulf of Martaban is not as strong as over the Gulf of Bengal, but due to the morphology of the Gulf of Martaban, it is possible to induce the bottom sediment. The sediment re-suspension is then carried out to the Andaman Sea by the generated wave. The reverse version of winds is observed during the SW monsoon season. During this season, the wind that originated from the southwest is directed towards the northeast of the gulf. The higher wind speed over the Bay of Bengal and Andaman Sea will induced the high wave. The high wave will push the sediment toward the north and northeast. The winds direction might explain the SSC covered area variation during these two seasons.

\section{River Discharges}

Gulf of Martaban received water influx from two large river systems, Irrawaddy and Salween. The combination of the Irrawaddy and Salween river systems could contribute to the averages of $697 \mathrm{~km}^{3}$ of water, $365 \mathrm{MT}$ of suspended material, and $162 \mathrm{MT}$ of dissolved material to the Gulf of Martaban and it surrounding area yearly (Robinson et al., 2007). Furthermore, freshwater and sediment discharge is highly seasonal (Rodolfo, 1969; Ramaswamy et al., 2004). Approximately $80 \%$ of the water and $92 \%$ of the sediment discharge occurs between 

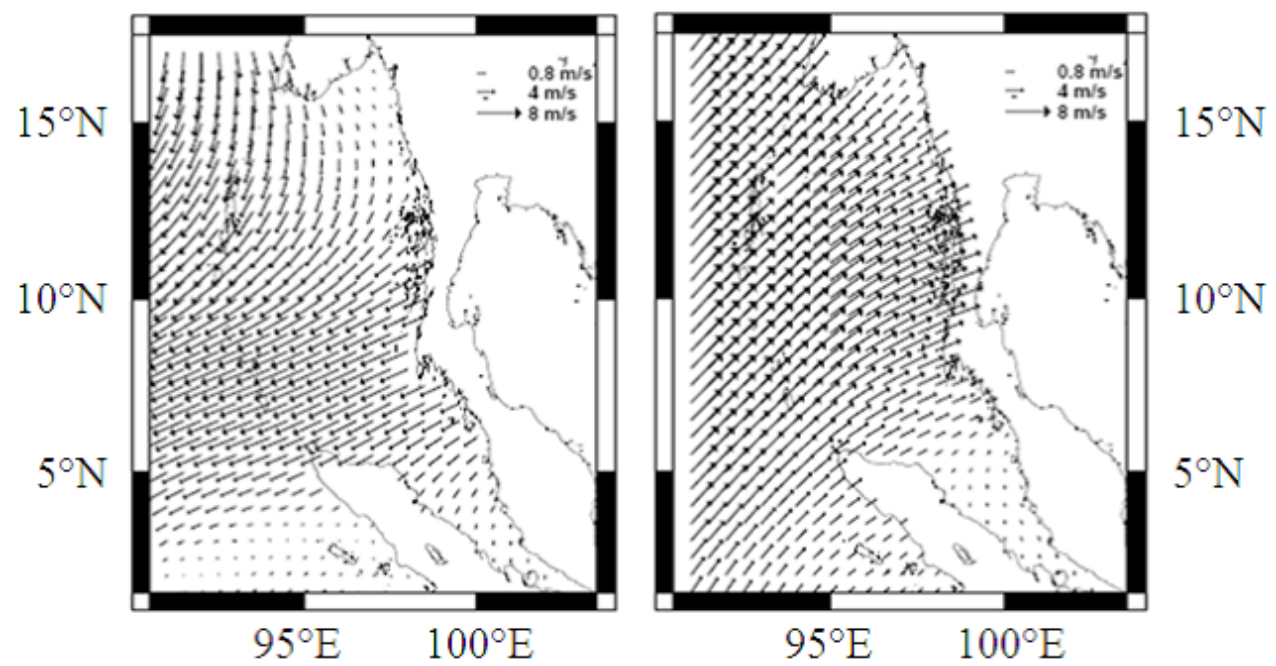

Fig. 7. Wind field during the (a) NE monsoon season; (b) SW monsoon season adapted from Rizal et al. (2012).
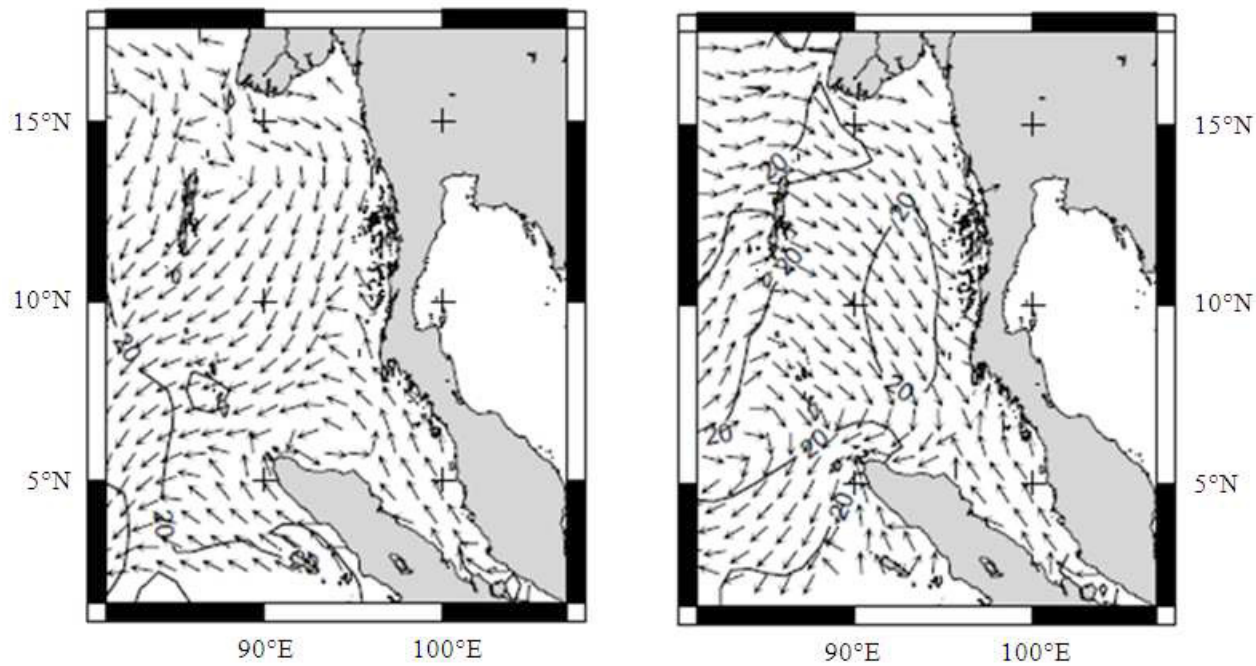

Fig. 8. The surface currents caused by tides, wind and heat flux derived from long-term (1985-2003) (a) December through February average (NE Monsoon) and (b) June through September average (SW Monsoon) based on HAMSOM. Contour values mean magnitude of velocity in $\mathrm{cm} / \mathrm{s}$ (Rizal et al., 2012).

June and November (Hedley et al., 2009). The above statement could be used to explain the presence of large area of high SSC (represented by the channel saturation area) over the river mouth and along the coastal line of the north part of the Gulf of Martaban during the SW monsoon season as compared to the NE monsoon season. The explanation for the small SSC cover area during the SW monsoon season has been clarified in the above discussion. 


\section{Tidal Wave}

During NE monsoon season, low river discharge is observed over the study area. But based on the above finding, the large SSC covered area is observed over the study area during this season as compared to the SW monsoon season. This result shows that river discharges did not contribute significant role for the increment in the SSC covered area. Ramaswamy et al., (2004) have concluded that the major change in the SSC is related to the spring-tide tidal cycles. Tidal ranges in the Gulf of Martaban are between 4 and $7 \mathrm{~m}$ with the highest tidal range of nearly $7 \mathrm{~m}$ is recorded at the western Gulf of Martaban. Strong tidal currents lead to substantial sediment suspension and re-suspension, resulting in the Gulf remaining turbid year-round. Figure 8 shows the general surface current caused by the tides over the study area according to Rizal et al. (2012).

\section{Conclusion}

In conclusion, sediment anomaly over Gulf of Martaban that based on remote sensing data was represented. The result shows that the sediment variation is highly varied with the monsoon season. Large sediment covered area is observed during NE monsoon season that occur from December to February for every years. The sediment covered area could stretch to the south and could cover an area of the latitude of $15^{\circ} \mathrm{N}$. Meanwhile, during the SW monsoon season, low sediment covered area could be seen. The sediment covered area in sparse shape not as homogenous as NE monsoon season. However, for the both seasons, high SSC is observed located along the coastal line that is located in the north and the east portion of the gulf. The variations in the SSC are contributed by the several factors such as monsoonal wind speed, river discharges and tidal current. Near to the shore line, the sediment is influenced mostly by the river discharge. Meanwhile the factor that dominates the turbidity far from the shore line is the tidal wave and wind speed. This factor could be clarified by the sediment cover area during the both seasons.

\section{Acknowledgements}

Analyses and visualisations used in this study were produced with the Giovanni online data system, developed and maintained by the NASA GES DISC. We would like to thank UiTM Kuala Terengganu, UMT and USM management for their support and encouragement. Our appreciation also goes to the MODIS team for all the valuable data provided. This project was founded by Universiti Teknologi MARA excellent grant No. 600-UiTMKD (PJI/RM U/ ST/DANA 5/2/1 Dst (08/20/2012).

\section{References}

Acker, J.G. \& Leptoukh G. (2007). Online analysis enhances use of NASA earth science data. Eos, Transactions American Geophysical Union, 88(2), 14-17. DOI: 10.1029/2007EO020003.

Chen, Z., Hu, C. \& Muller-Karger F. (2007). Monitoring turbidity in Tampa Bay using MODIS/Aqua 250-m imagery. Remote Sens. Environ., 109(2), 207-220. DOI: 10.1016/j.rse.2006.12.019.

Chu, V.W., Smith, L.C., Rennermalm, A.K., Forster, R.R., Box, J.E. \& Reehy N. (2009). Sediment plume response to surface melting and supraglacial lake drainages on the Greenland ice sheet. Journal of Glaciology, 55(194), 1072-1082. DOI: $10.3189 / 002214309790794904$. 
Curran, P.J. \& Novo E.M.M. (1988). The relationship between suspended sediment concentration and remotely sensed spectral radiance: a review. J. Coas. Res., 4(3), 351-368. URL: http://www.jstor.org/stable/4297423

Doxaran, D., Froidefond, J.M. \& Castaing P. (2003). Remote-sensing reflectance of turbid sediment-dominated waters. Reduction of sediment type variations and changing illumination conditions effects by use of reflectance ratios. Applied Optics, 42(15), 2623-2634. http://www.opticsinfobase.org/ao/abstract.cfm?URI=ao-42-15-2623

Hadden, R.L. (2008). The Geology of Burma (Myanmar): An Annotated Bibliography of Burma's Geology, Geography and Earth Science. Alexandria: Geospatial Information Library.

Hedley, P. J., Bird, M.I. \& Robinson R.A. (2010). Evolution of the Irrawaddy delta region since 1850. The Geographical Journal, 176(2), 138-149. DOI: 10.1111/j.1475-4959.2009.00346.x.

Hu, C., Chen, Z., Clayton, T.D., Swarzenski, P., Brock, J.C. \& Muller-Karger F.E. (2004). Assessment of estuarine water-quality indicators using MODIS medium-resolution bands: Initial results from Tampa Bay, FL. Remote Sens. Environ., 93(3), 423-441. DOI: 10.1016/j.rse.2004.08.007.

Kirk, J.T.O. (1994). Light and photosynthesis in aquatic ecosystems. Cambridge: Cambridge University Press.

Leptoukh, G., Cox, S., Farley, J., Gopalan, A., Mao, J. \& Berrick S. (2007). Exploring NASA and ESA atmospheric data using Giovanni, the online visualization and analysis tool. ENVISATSymp., Montreux, Apr. 23-27, 2007.

Long, C.M. \& Pavelsky T. M. (2013). Remote sensing of suspended sediment concentration and hydrologic connectivity in a complex wetland environment. Remote Sens. Environ., 129, 197-209. DOI: 10.1016/j.rse.2012.10.019.

Miller, R.L. \& McKee B.A. (2004). Using MODIS Terra $250 \mathrm{~m}$ imagery to map concentrations of total suspended matter in coastal waters. Remote Sens. Environ., 93(1-2), 259-266. DOI: 10.1016/j.rse.2004.07.012.

Mobley, C.D. \& Mobley C.D. (1994). Light and water: Radiative transfer in natural waters (Vol. 592). San Diego: Academic Press.

Moreno-Madrinan, M.J., Al-Hamdan, M.Z., Rickman, D.L. \& Muller-Karger F.E. (2010). Using the surface reflectance MODIS Terra product to estimate turbidity in Tampa Bay, Florida. Remote Sensing, 2(12), 2713-2728. DOI: $10.3390 / \mathrm{rs} 2122713$.

Pavelsky, T.M. \& Smith L.C. (2009). Remote sensing of suspended sediment concentration, flow velocity, and lake recharge in the Peace-Athabasca Delta, Canada. Water Resources Research, 45(11). DOI: 10.1029/2008WR007424.

Petus, C., Chust, G., Gohin, F., Doxaran, D., Froidefond, J.M. \& Sagarminaga Y. (2010). Estimating turbidity and total suspended matter in the Adour River plume (South Bay of Biscay) using MODIS 250-m imagery. Continental Shelf Research, 30(5), 379-392. DOI: 10.1016/j.csr.2009.12.007.

Ramaswamy, V., Rao, P.S., Rao, K.H., Thwin, S., Rao, N.S. \& Raiker V. (2004). Tidal influence on suspended sediment distribution and dispersal in the northern Andaman Sea and Gulf of Martaban. Marine Geology, 208(1), 33-42. DOI: $10.1016 /$ j.margeo.2004.04.019.

Rao, P. S., Ramaswamy, V. \& Thwin S. (2005). Sediment texture, distribution and transport on the Ayeyarwady continental shelf, Andaman Sea. Marine Geology, 216(4), 239-247. DOI: 10.1016/j.margeo.2005.02.016.

Ritchie, J.C., Schiebe, F.R. \& McHenry J. (1976). Remote sensing of suspended sediments in surface waters. Photogrammetric Engineering and Remote Sensing, 42(12), 1539-1545.

Rizal, S., Damm, P., Wahid, M.A., Sundermann, J., Ilhamsyah, Y. \& Iskandar T. (2012). General circulation in the Malacca strait and Andaman sea: a numerical model study. American Journal of Environmental Sciences, 8(5), 479-488. DOI: 10.3844/ajessp.2012.479.488.

Robinson, R.A.J., Bird, M.I., Oo, N.W., Hoey, T.B., Aye, M.M., Higgitt, D.L. \& Win S.L. (2007). The Irrawaddy River sediment flux to the Indian Ocean: the original nineteenth-century data revisited. The Journal of Geology, 115(6), 629-640. DOI: 10.1086/521607.

Rodolfo, K.S. (1969). Sediments of the Andaman basin, northeastern Indian Ocean. Marine Geology, 7(5), 371-402. DOI: 10.1016/0025-3227(69)90014-0.

Rodríguez-Guzmán, V. \& Gilbes-Santaella F. (2009). Using MODIS $250 \mathrm{~m}$ imagery to estimate total suspended sediment in a tropical open bay. International Journal of Systems Applications Engineering and Development, 3(1), $36-44$.

Salomonson, V.V., Barnes, W., Maymon, P.W., Montgomery, H.E. \& Ostrow H. (1989). MODIS: Advanced facility instrument for studies of the Earth as a system. Geoscience and Remote Sensing, IEEE Transactions on, 27(2), 145-153. DOI: $10.1109 / 36.20292$.

Wang, F., Zhou, B., Xu, J., Song, L. \& Wang X. (2009). Application of neural network and MODIS 250 m imagery for estimating suspended sediments concentration in Hangzhou Bay, China. Environ. Geol., 56(6), 1093-1101. DOI: $10.1007 /$ s00254-008-1209-0.

Wyrtki, K. (1961). Physical oceanography of the southeast Asian waters. California: University of California. 